\title{
Agriculture and Human Values
}

Agriculture and Human Values is a refereed interdisciplinary journal devoted to fostering increased awareness and appreciation of the sociological, anthropological, historical, and philosophical issues surrounding agricultural practices and policies, natural resource use, and technologies involved in the production of food and fiber. Agriculture and Human Values encourages submissions of papers reflecting empirical research, as well as more theoretical or conceptual work in the social sciences and philosophy. Agriculture and Human Values is published quarterly.

\section{Recent Articles Include...}

Lawrence Busch and William Lacy: Agricultural Policy: Issues for the '80s and Beyond

Frederick Buttel: The Land-Grant System: A Sociological Perspective on Value Conflicts and Ethical Issues

Pierre Crosson: Agricultural Land: A Question of Values

Nicholas Ellig: Issues in the Analysis of Contemporary Farm Protest

Cornelia Flora: Women and Agriculture

C.A. Francis: Rationality of New Technology for Small Farmers in the Tropics

Philip L. Martin: Labor in California Agriculture

Joseph Molnar and Lionel Beaulieu: Societal Implications of Changes in the Organization of Agricultural Production

Carolyn Sachs: Womens' Work in the U.S.: Variations by Region

Articles ( 3 copies), book reviews, and inquiries should be addressed to:

Richard P. Haynes, Editor, Agriculture and Human Values

Department of Philosophy, University of Florida, Gainesville, FL 32611

Subscriptions: 1987, 4 issues/1 year should be addressed to:

Managing Editor, Agriculture and Human Values

Department of Philosophy, University of Florida

Gainesville, FL 32611

Individuals: $\$ 20.00 \quad$ Institutions: $\$ 30.00 \quad$ International: add. $\$ 10.00$ 


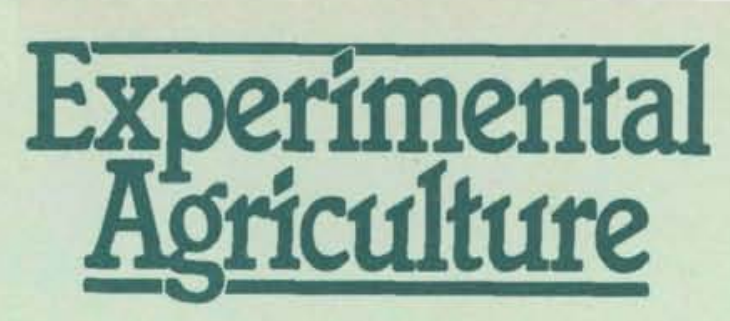

Volume 23, Number 2 April 1987

\section{CONTENTS}

P. J. M. Cooper, P. J. Gregory, D. Tully and H. C. Harris: Improving Water Use Efficiency of Annual Crops in the Rainfed Farming Systems of West Asia and North Africa (Farming Systems Series - Number 5)

A. L. Singh and P. K. Singh: The Use of Azolla pinnata Isolates as Organic Nitrogen Sources for Lowland Rice (Oryza sativa)

J. Halevy: Efficiency of Isobutylidene Diurea, Sulphur-coated Urea and Urea plus Nitrapyrin, Compared with Divided Dressings of Urea, for Dry Matter Production and Nitrogen Uptake of Ryegrass

J. N. Woolley and W. Rodríguez: Cultivar X Cropping System Interactions in Relay and Row Intercropping of Bush Beans with Different Maize Plant Types

J. M. O. Eze: Growth of Amaranthus hybridus (African Spinach) under Different Daylight Intensities in the Dry Season in Southern Nigeria

B. B. Reddy, B. C. Ghosh and M. D. Reddy: Effect of Transplanting and Seedling Age on Stand Establishment and Grain Yield of Rice in Rainfed Lowland (Intermediate Deep-water) Conditions

H. M. Ishag, A. T. Ayoub and M. B. Said: Cotton Leaf Reddening in the Irrigated Gezira

O. Guzman and L. Gomez: Permanence of Free Water on Coffee Leaves

A. Muimba-Kankolongo and K. Phuti: Relationship of Cassava Mosaic Severity in Planting Material to Mosaic Development, Growth and Yield of Cassava in Zaire

Book Reviews

Notes for Contributors

\section{CAMBRIDGE UNIVERSITY PRESS}

The Pitt Building, Trumpington Street, Cambridge CB2 IRP 32 East 57th Street, New York, NY 10022, USA 10 Stamford Road, Oakleigh, Melbourne 3166, Australia 